ANDRZEJ K. LINK-LENCZOWSKI

UNIWERSYTET JAGIELLOŃSKI

\title{
Anglia lat 1660-1685. Władza, polityka i społeczeństwo
}

Śmierć Olivera Cromwella w roku 1658 wkrótce unaoczniła elicie władzy, która formalnie tworzył Parlament kadłubowy i armia, że dla skutecznego rządzenia konieczny jest kompromis pomiędzy tymi siłami. „Kadłub” i wojsko darzyły się wzajemna niechęcia, ale początkowo obie siły były zgodne w dwóch kwestiach: uważano, że restauracja Stuartów i powołanie na tron Karola II jest na razie niewykonalne i że niezbędne jest zaspokojenie pretensji finansowych wojska, coraz mocniej buntującego się przeciwko dowódcom. Wkrótce parlament, który nie osiagnął porozumienia $z$ generałami, został przez nich rozpędzony. Warunki życia w miastach i na wsi pogarszały się, aktywizowali się wszyscy krytycy pogłębiającego się chaosu. Coraz częściej zabierali głos religijni radykałowie, wydawałoby się skutecznie ( $\mathrm{z}$ wyjątkiem może kwakrów) uciszeni przez wojskowych. Wkrótce głównym rozgrywającym stał się generał George Monk. Niedługo, ponownie zwołany, Parlament kadłubowy na żądanie Monka przywrócił do swego grona posłów z Długiego Parlamentu. Miał on przygotować nowe wybory, a następnie się rozwiązać. Już wówczas większość posłów chciała rokowań z przebywającym w Holandii Karolem Stuartem. W kwietniu 1660 r. zgromadzenie posłów, zwące się zjazdem (konwencja), stwierdziło, że należy zaprosić króla do powrotu1. Armia Nowego Wzoru została na razie zmniejszona do 28342 ludzi. Wkrótce dokonała się jej dalsza redukcja.

1 G. D avies, The Restoration of Charles II 1658-1660, Oxford 1955, passim; G. Holm e s, The making of a Great Power. Late Stuart and early Georgian England 1660-1722, London 1995, s. 3 i n. 
Warunki powrotu, jak wiadomo, były dość jasne, wątpliwości miała rozwiać wydana przez króla Deklaracja z Bredy, mająca zadowolić większość polityków i umiarkowanej opinii publicznej. Król zresztą sygnował objęcie swą łaską również protestanckich dysydentów, co nie było w smak elicie politycznej traktującej ich jako czynnik w ogromnym stopniu przyczyniajacy się do destabilizacji struktur państwa. Natomiast Kościół episkopalny musiał być przywrócony, będąc - podobnie jak instytucja monarchii - podstawowym elementem systemu władzy opisywanego jako „uosabiajacy dla ludu system wartości, do których odnosili swe życie”. Rekonstrukcja systemu władzy musiała mieć, podobnie jak poprzednio jego zburzenie, implikacje religijne. Pozostawał jednak problem religijnych nonkonformistów, przede wszystkim umiarkowanych purytan - prezbiterian, niezwykle wpływowych w Konwencji, która ogłosiła się w pełni legalnym parlamentem.

Przywrócenie monarchii i dość umiarkowana polityka Karola II miała przekonać wszystkich, że tworzący się nowy układ relacji pomiędzy królem i parlamentem będzie oparty generalnie także na kompromisie w sprawach religijnych. Rozwiazanie innych spraw wydawało się relatywnie prostsze. Natomiast stosunek do Kościoła anglikańskiego, purytan i innych nurtów religijnych oraz katolików mógł stać się w krótkim czasie przedmiotem sporu religijnego, a zarazem politycznego, mogacego rozsadzić ramy kompromisu politycznego, bez którego groziłby powrót do zaburzeń i wojny domowej. Tego, podobnie jak niedawnych rządów generał-majorów powszechnie się obawiano zarówno na wsi, jak i w miastach. Na razie próby porozumienia pomiędzy anglikanami a prezbiterianami (konferencja w Worcester House) nie dały rezultatów wobec oporu w parlamencie, a autorytet biskupów anglikańskich i w ogóle strzegących kwestii religijnych, $\mathrm{u}$ wielu obserwatorów sceny politycznej był postrzegany sceptycznie. Znamienne były spostrzeżenia Samuela Pepysa stwierdzającego w październiku 1660 r., że „religia nie jest niczym jak humorem, a estyma w jakiej ja mamy, przemija, tak jak i wszystkie rzeczy", biskupów wychodzacych z Opactwa Westminsterskiego opisywał jako "cudaków”, na których niewielu patrzyło „z jakakkolwiek miłością czy respektem”2. Styczniowe londyń-

2 Dziennik Samuela Pepysa, wybór, przekł. i przyp. M. Dąbrowskiej, t. I, Warszawa 1978, s. 112-113. W następstwie wydarzeń $z$ lat 1640-1660 podziały religijne traktowano, jak się wydaje, mniej serio w życiu prywatnym. Żona Pepysa była katoliczką. Mimo to wyrażał on w grudniu 1668 r. radość z tego, że wybiera 
skie rozruchy wszczęte w roku 1661 przez ludzi Kościoła Piątej Monarchii pod wodza Thomasa Vennera zostały stłumione. Od nowego parlamentu, nazwanego „parlamentem kawalerów”, który zebrał się z początkiem maja $1661 \mathrm{r}$. oczekiwano zdecydowanej polityki w obawie przed spiskami zwolenników republiki i religijnych radykałów. Oddziaływało to na postawy nowo wybranych posłów, przyczyniając się do usztywnienia stanowiska wobec nonkonformistów. $Z$ drugiej strony ułatwiało królowi odgrywanie roli człowieka starającego się stawać ponad podziałami religijnymi i unikającego skrajności w tych materiach. Kolejna konferencja anglikańsko-purytańska, rozpoczęta w kwietniu 1661 r., ostatecznie rozeszła się w lipcu tego roku bez podjęcia uchwał, a inicjatywa Izby Lordów, zmierzająca do przyznania większych uprawnień katolikom, nie zyskała większości3. Wszystko to sprawiło, że przywrócenie Episkopatu wydawało się kończyć budowę struktur kościelnych opartych na dawnym fundamencie wiary, prawa i porządku. Powrót do czasów sprzed roku 1642 nie był jednak w pełni możliwy, gdyż zbyt wiele zmian w świadomości zbyt wielu ludzi powodowało inne niż w pierwszej fazie konfliktu w latach czterdziestych zachowania indywidualne przekładające się na odniesienia do konfliktów politycznych i religijnych sporów. Dostrzegał to główny doradca Karola II Edward Hyde Clarendon, który pisał, że wielość sekt nonkonformistycznych zmieniła postrzeganie różnic między ludźmi, niszcząc trwałe elementy społecznej hierarchii ${ }^{4}$. Byłaby to więc jakby inna jakościowo społeczna mobilność, kontestujacca dawna hierarchię.

Parlament kawalerów nie mógł być jednak widownia religijnych dysput i zbyt ostrych sporów, gdyż $z$ natury swej musiał się opowiadać za kontynuacją przeszłości, z nawiazywaniem do rozwiazań znanych od dawna, do swoistej „politycznej Arkadii”. Musiał, choćby werbalnie, opowiadać się za dawnym ładem w imię zabezpieczenia porzadku i poszanowania dawnych praw. Temu miała służyć doraźna gra i strategia polityczna na nadchodzace lata. Było to tym łatwiejsze, że arystokracja, szlachta, a także warstwy średnie i niższe pragnęły bezpieczeństwa. Początkowo więc nie

się z nim do kościoła, stwierdzając „wierzę zaiste, iż jest bogobojna i szczerze prawowierna, jednak widzę, że nie jest snadź tak sroga katoliczka, aby nie chciała pójść ze mną do kościoła, co mnie cieszy". Cyt. za: ibidem, t. II, s. 399.

${ }^{3}$ G. Holm e s, op. cit., s. 3.

4 „All Relations were confounded by the several Sects in religion, which discountenanced all Forms of Reverence and respect". Por. Ch. Hill, Puritanism and Revolution, London 1962, s. 209-210. 
były to dobre czasy dla politycznych i społecznych eksperymentatorów.

We wczesnych latach rząów, za eksperymentatora, rzecznika „nowego”, można by prędzej uznać Karola II Stuarta, człowieka o szerokich horyzontach, twardego i przebiegłego polityka, ale zwolennika umiaru, który nie upierał się, że jego pomysły musza być zawsze realizowane, ale twardo, umiejętnie, bronił swych racji, choćby w czasie kryzysu ekskluzyjnego. Wiedział jednak, do jakiego punktu może powiększać determinację swych poddanych w sprawach religijnych i wszelkich innych. Był ostrożny, tym bardziej że Parlament kawalerów, z którym dzielił rządy przez większość swego panowania, był wobec niego zasadniczo nieufny i nie miał np. ochoty na finansowanie stałej armii pozostajacej w ręku królewskim (Armia Nowego Wzoru została, jak wiadomo, ostatecznie rozwiązana; zresztą w nowej, politycznej rzeczywistości jej utrzymanie było niemożliwe). Król dysponował w roku 1661 ograniczona liczba 3000 żołnierzy piechoty i kawalerii.

W marcu 1662 r. parlament zaaprobował anglikański Modlitewnik w lekko poprawionej wersji. Dla sekciarzy nie była to dobra nowina. W tymże roku uchwalono Akt o Jedności Wiary, którego celem było pozbycie się prezbiteriańskich pastorów wprowadzonych wcześniej na parafie. Rzeczywiście usunięto około $20 \%$ pastorów, a resztę skutecznie zastraszono, choć nie zdołano wyeliminować zjawiska różnych form praktyk religijnych. Za najgroźniejszych uznano kwakrów, i to przeciwko nim skierowany był Akt o Konwentyklach z 1670 r. ${ }^{5}$ Stąd wynikało widzenie odstępstwa od anglikanizmu jako raczej przejawu politycznego niezadowolenia niż autentycznego poszukiwania prawdziwej drogi do zbawienia. Niezależnie od tego, czy taki pogląd uznamy za w pełni słuszny, różnice postrzegania podziałów religijnych $\mathrm{w}$ porównaniu $z$ czasami wojny domowej wydaja się istotne. Korona, kładąc nacisk na „powrót do normalności", stwarzała warunki do spokojnego konsumowania zdobyczy z czasów wojny domowej. Dotyczyło to nie tylko posiadaczy ziemskich, obojętne dawnych czy nowych, ale także zamożniejszych rzemieślników, nie mówiąc o kupcach i przedsiębiorcach. Stąd dążenie Karola II w pierwszych latach panowania do minimalizowania ostrych konfliktów politycznych, przynajmniej tak długo, jak było to możliwe ${ }^{6}$. Gdy np. zorientował się, że pewna sympatia,

5 J. Mille r, Stuartowie, Warszawa 2008, s. 159-162.

6 I d e m, After the Civil Wars, London 2000, s. 105. 
którą okazywał irlandzkim katolikom budzi bardzo silny opór parlamentu, natychmiast się z niej „wycofał”, nie robiąc niczego, co wzburzyłoby opinię protestancką. Ale tam, gdzie nie budziło to poważniejszych kontrowersji, szczególnie w pierwszym okresie panowania, a więc $\mathrm{w}$ czasach, gdy był postrzegany przez elity znacznie życzliwiej niż pod koniec rządów, starał się rządzić nie przejmując się zbytnio parlamentem. Było to możliwe, gdyż dysponował sprawna administracją finansowa, a na poczattku panowania przyznano mu dochody mające przynosić milion dwieście tysięcy funtów. Był więc niezależny. Wystarczało to w czasach pokoju, natomiast zaangażowanie się Korony w aktywne działania na arenie międzynarodowej już od samego początku stwarzało kryzysowa sytuację, bardzo utrudniając relacje między władca a parlamentem, ułatwiajac natomiast działanie tym, którzy politykę zagraniczna traktowali jako doskonały punkt wyjścia do totalnej krytyki Stuartów, prowadzonej z użyciem wszelkich argumentów, także religijnych. W nowej, dynamicznie się rozwijającej sytuacji Anglii, po traktacie z Francja podpisanym w Dover w 1670 r., krytyka nie była widoczna, ale szczególnie mocno pęknięcie w opiniach na temat działań Stuartów ujawniło się w latach 1672-1673. Było to związane $z$ ocena polityki zagranicznej Karola, rzeczywiście niezręcznej i nieskutecznej, choć $z$ drugiej strony był on pozbawiony finansowego wsparcia parlamentu. Dlatego Karol II próbował dokonać pewnego otwarcia w stronę katolików i nonkonformistów wydając w 1672 r. Deklaracje o Tolerancji Religijnej w związku $z$ rozpoczęciem wojny $z$ Holandią. Skłoniło to wielu do zaostrzenia ataków na Karola i Jakuba, ks. Yorku, oskarżanych o zamiar wprowadzenia katolicyzmu i „samowoli swych rządów" (w domyśle absolutyzmu). Było jasne, że parlament przyzna subsydia wojenne, ale za cenę anulowania wspomnianej deklaracji. Król ustapił, zresztą w obliczu klęski w wojnie holenderskiej, akt tolerancyjny został odwołany, a w jego miejsce w 1673 r. uchwalono Akt o Przysiędze. Na jego mocy wszystkie osoby zajmujące urzędy musiały przyjąc komunię w obrządku anglikańskim i opowiedzieć się m.in. w szczególności przeciwko dogmatowi o przemianie chleba i wina w czasie Eucharystii w ciało i krew Chrystusa. Celowo zmuszano w ten sposób katolików do opuszczenia urzędów cywilnych i wojskowych. Najważniejsza ofiarą tego aktu był książę Jakub (jak wiadomo już wówczas katolik), który opuścił stanowisko lorda admirała. Karol natomiast dostał pieniądze, ale doraźnie zapłacił za to bardzo wysoką cenę polityczną, gdyż uważano odtąd, że jest skłonny do wprowadzenia „papi- 
stowskich" rządów. Wojna $z$ Holandią szła zresztą, jak wiadomo, źle, kolejne subsydia parlamentu mogły oznaczać wzmocnienie jego kontroli nad poczynaniami króla. Najistotniejsze, że niepowodzenia polityczne warunkowały ograniczenie pola manewru Korony w sprawach wewnętrznych, ale to głównie podejrzenia, że król wraz $z$ bratem zamierzaja przywrócić katolicyzm, blokowały większość inicjatyw politycznych dworu. Polityczny pat owocował dalszym wzrostem napięcia pomiędzy dworem a parlamentem u schyłku lat siedemdziesiatych.

W takiej atmosferze pojawił się Titus Oates ze swymi rewelacjami o papistowskim spisku na życie króla. Sprawa ta jest zbyt dobrze znana, aby ja po raz kolejny przywoływać, miała jednak bardzo poważne następstwa polityczne, tym bardziej że złe relacje między dworem a parlamentem spowodowały lawinę plotek rozprzestrzenianych $\mathrm{w}$ ulotnych drukach o tym, że armia zebrana przez króla przeciwko Francji umożliwi wprowadzenie absolutyzmu w Anglii. Żartowano i plotkowano, że Izba Gmin chce wojny bez armii, a dwór chce armii bez wojny ${ }^{7}$. Choć Karol II rozegrał sprawę Oatesa bardzo zręcznie, nie przysłużyła się ona na dłuższa metę księciu Yorku. Kraj wkroczył w tzw. kryzys ekskluzyjny (luty 1679 marzec 1681). Ten rzeczywiście poważny kryzys polityczny, niezależnie od jego implikacji w polityce wewnętrznej i zagranicznej, ułatwił bardzo silna artykulację tendencji utożsamiajacych protestantyzm $z$ oporem przeciwko wszelkiej samowoli, przede wszystkim (ale nie tylko) płynącej bezpośrednio $z$ dworu. Nie udało się jednak opozycji wykluczyć Jakuba jako pretendenta do tronu, król trzykrotnie rozwiąał parlament. Najważniejsza była wyraźna krystalizacja opinii publicznej wokół sprawy stosunku do pochodzenia i natury władzy królewskiej oraz jej zakresu. Kwestia katolickiej sukcesji nabierała zdumiewającego wydźwięku. J. Miller zwraca uwagę, że nawet gdy anglikańskie duchowieństwo broniło prawa Jakuba do tronu wynikającego po prostu $z$ urodzenia, było krytykowane jako „papiści w przebraniu” i „zwolennicy papizmu”. Każde napięcie ożywiało więc stare „kalki” i stereotypy, które w jakimś stopniu odzwierciedlały rzeczywiste zagrożenia i podziały.

Król jednak poradził sobie $z$ kryzysem bardzo dobrze. Jeżeli czynił ustępstwa, to w drugorzędnych sprawach. Zreszta zawsze

7 Dokładny opis spisku i jego konsekwencji daje D. O g g, England in the Reign of Charles II, vol. II, Oxford 1955, s. 559-619; J. M ill e r, Stuartowie..., s. 181 i n. 8 J. Miller, Stuartowie..., s. 183. 
sprawiał wrażenie, mylące przeciwników, że jest skłonny w dużym stopniu liczyć się $z$ ich zdaniem. Nie użył siły, ale nie pozwolił odebrać sobie istotnych prerogatyw dotyczacych przede wszystkim prawa mianowania sędziów, oficerów i wykorzystując zręcznie bardzo ważne prawo kontroli aparatu prawnego, obsadzał go swymi ludźmi ${ }^{9}$. Król miał wojsko wokół stolicy, a milicja londyńska była wobec niego lojalna. Nie było warunków do rozpętania wojny domowej, bo zbyt świeże były wspomnienia $z$ lat rewolucyjnych. $\mathrm{Na}$ platformach wożono jezuitów z krwawymi sztyletami, rozwiazłe zakonnice, „papistowskich spiskowców”, „papistów w przebraniu” i „papieża”, którego kukłę palono (listopad 1679 - listopad 1680). Służyło to przede wszystkim wzmacnianiu procesów identyfikacyjnych zwolenników i przeciwników Stuartów, ale nie prowadziło do decydujacego starcia o władzę, do którego rozważania na temat władzy królewskiej miały być wstępem. Podział opinii był już jednak zjawiskiem trwałym, w jakimś sensie „zakodowanym” w dyskursie publicznym, szczególnie gdy dotyczył on osoby i przyszłości Jakuba - następcy tronu, ale w gruncie rzeczy wszystkich spraw publicznych. Dyskusja na każdy temat stawała się od razu sporem do szpiku kości politycznym, ze spora domieszką demagogii. W tej sytuacji Karol II mógł liczyć na poparcie środowisk bojacych się nadmiernego rozhuśtania nastrojów w kraju i skłonnych szukać w monarchii obrońcy naturalnego ładu i porzadku. Należeli do nich, jak wiadomo, ludzie, których coraz częściej zwano, zrazu pogardliwie, torysami ${ }^{10}$. Tendencje te nasiliły się jeszcze w roku 1683 po odkryciu tzw. Spisku Domu Zbożowego, kiedy to miano rzekomo zamordować Karola i Jakuba w drodze $z$ Newmarket do Londynu. Algernona Sidneya i lorda Williama Russella stracono pod zarzutem zdrady stanu. Korona pokazywała, że ma środki, aby zniszczyć swoich przeciwników ${ }^{11}$. W czerwcu 1683 r. City otrzymała królewski zarząd komisaryczny. Londyn nie ochronił swej karty praw miejskich.

W październiku 1684 r. Karol II i Jakub wizytowali oddziały szkolone w Putney. Propaganda torysowska tryumfalnie głosiła

9 M. Markiewicz, Absolutyzm - wymysł historyków czy rzeczywistość w Anglii Jakuba II i Francji Ludwika XIV, „Studia Historyczne” 1993, R. XXXVI, z. 4, s. $458-460$.

10 Relacja o partiach politycznych $\mathrm{w}$ momencie wstapienia na tron Jerzego I w roku 1714 por. A. Lin k-Le n c zow s ki, W. Mag d zi a r z, A. S ow a, Historia powszechna 1648-1789. Wybór tekstów źródłowych, Kraków 1976, s. 73-75.

11 D. O g g, op. cit., s. 620-656. 
wówczas w pamfletach, że Korona obecnie dysponuje stała armią, aby mieć obronę przed wigami, ich stronnikami i siejącymi niezgodę ${ }^{12}$.

Podziały religijne okresu Restauracji, sięgające czasów wcześniejszych, kształtując ludzkie zachowania wobec współczesnych wyzwań, stały się czynnikiem określającym zachowanie jednostek i grup w obliczu konkretnych politycznych wydarzen. W jakimś zakresie (trudno dokładnie określić mechanizm takiej przemiany) odniesienia do religii i religijnych podziałów coraz częściej stawały się artykulacja sporów czysto politycznych. Jeszcze długo jednak dyskurs polityczny spowijała religijna szata, stająca się coraz częściej swego rodzaju konwencja, ale ważną dla jego uczestników. Decydujace znaczenie miała zdolność Korony, wykazywana w latach 1681-1685, do mobilizacji swoich zwolenników w imię hasła „powrotu do normalności”, zachowania zdrowego rozsądku i „prawdziwej religii”. Im bardziej radykalizowali się wigowie, snując różne konspiracyjne plany, tym łatwiej było Stuartom ukazywać ich jako nieodpowiedzialnych politykierów. Co ważniejsze, było to doraźnie działanie skuteczne ${ }^{13}$.

12 J. M ille r, Stuartowie..., s. 186-192; D. O g g, op. cit., s. 656.

13 T. H a r r is, Restoration. Charles II and his Kingdoms 1660-1685, London 2006, s. 416-417; R. H u t t o n, Charles the Second. King of England, Scottland and Ireland, Oxford 1989, s. 405-445. 